\title{
Hvordan gik det med lokaldemokratiet?
}

\author{
Sune Welling Hansen, Lektor, Institut for Statskundskab, Syddansk Universitet
}

I artiklen gives et review af studier, der har undersøgt de lokaldemokratiske konsekvenser af Strukturreformen. Der er fokus på studier, der har anvendt kommunesammenlægningerne, som var del af reformen, til at studere sammenhængen mellem størrelsen på politiske systemer og demokratiets tilstand. De effekter, som studierne finder belæg for, er typisk svage til moderate i styrke og negative, således at stigninger i størrelse svækker demokratiets tilstand. Det overordnede billede som fremkommer er, at studiernes resultater i høj grad stemmer overens med den eksisterende litteratur.

\section{Introduktion}

Siden Strukturreformen trådte i kraft i 2007 (og i årene op til), er der blevet forsket meget i dens konsekvenser for lokaldemokratiet (såvel som andre dele af det kommunale selvstyre). ${ }^{16}$ Den store opmærksomhed, som reformen har fået, er helt forventelig, da Strukturreformen var meget omfattende, og da denne slags reformer forekommer relativt sjældent $i$ et land (hvorfor det jo gælder om at undersøge dem når muligheden byder sig). ${ }^{17}$ Derfor er det nu, næsten ti år efter reformens ikrafttræden (og seks år siden et lignende review sidst blev foretaget; Olsen 2010), også et godt tidspunkt at gøre status på, hvad forskningen har fundet frem til.

Lokaldemokrati er et begreb med mange dimensioner, hvoraf nogle er nært forbundne med andre dele af det kommunale selvstyre. Skal man vurdere, hvordan det står til med lokaldemokratiet i de danske kommuner, er det selvsagt centralt at se på borgernes politiske meninger, holdninger og adfærd, men det er på ingen måde begrænset til dette. Det er for eksempel også et spørgsmål om, hvorvidt det kommunale selvstyre reelt $e r$ et selvstyre på økonomisk og anden vis, således at man $\mathrm{i}$ kommunerne kan tilpasse sig til sine borgeres lokale præferencer, hvilket er kongstanken i det danske kommunale selvstyre. Ligesom det også er et spørgsmål, om der er et egentligt lokalt partisystem, eller blot en spejling af det landspolitiske system uden den lokale særegenhed, som er tanken

\footnotetext{
16 'Lokalt' kan selvsagt også vedrøre andre niveauer end det kommunale, da det fx også kan bruges til at betegne byer, bydele eller sogne. Men i denne artikel anvendes førstnævnte betydning.

${ }^{17}$ Men interessen er stadig ikke naturgiven, hvilket man så med sammenlægningerne gennemført i 1960erne, som ikke fik meget forskningsmæssig opmærksomhed. Det eneste større projekt, som forfatteren er bekendt med, er undersøgelsen gennemført af Oluf Ingvartsen, Palle Mikkelsen, Henning Strøm og Carsten Boll, udgivet i seksbindsserien "Kommunalreformen i Danmark" i 1991 (udgivet af forlaget Kommuneinformation). Og heri siges der ikke sønderligt meget om lokaldemokratiet.
} 
med selvstyret. Og hvis ingen af delene er tilfældet, kan man sætte spørgsmålstegn ved, om der reelt er lokaldemokrati i kommunerne. På samme måde er det for eksempel også centralt, at de lokale folkevalgte har arbejdsvilkår, der sætter dem i stand til at varetage deres mandat på fornuftig vis. Og på den måde kan man blive ved. Listen af relevante dimensioner er meget, meget lang, og i et review som dette kan man ikke gøre sig forhåbninger om at komme i nærheden af noget, der er fuldt dækkende. Jeg har derfor valgt et kompromis, hvor jeg først omtaler en række centrale forskningsbidrag, som - i forskellige grader - har undersøgt Strukturreformens konsekvenser for lokaldemokratiet; og dernæst giver jeg et dybdegående review af effektstudier (hvor man undersøger om et eller flere forhold påvirker andre forhold), der har undersøgt borgernes politiske meninger, holdninger og adfærd. Reviewet er opbygget således, at jeg i det følgende beskriver den ovenfor omtalte forskning i den angivne rækkefølge, hvilket efterfølges af en diskussion af resultaterne i sidstnævnte studier.

\section{Studier af Strukturreformen og lokaldemokratiet}

Der er som sagt blevet skrevet meget om Strukturreformen, og om kommunesammenlægningerne, som var en del af reformen, herunder om konsekvenserne for lokaldemokratiet. For det første er der udkommet et antal antologier, som anlægger et bredere perspektiv på Strukturreformen, og som derigennem også berører lokaldemokratiet i kommunerne. Her skal særligt nævnes Blom-Hansen et al. (2006), antologierne udgivet af Forskningsprogrammet om Strukturreformen (Buch og Elklit 2007; Elklit og Pedersen 2006; og Mouritzen 2006), og de sidste par kommunalvalgsbøger (førnævnte Buch og Elklit 2007; og Elklit og Kjær 2013).

For det andet har en række studier undersøgt problemstillinger, som i forskellig grad - men ikke nødvendigvis direkte - relaterer sig til Strukturreformens betydning for lokaldemokratiet. I det følgende nævnes en række studier, som har undersøgt forskellige problemstillinger, der kan organiseres jævnfør Figur 2; denne er inspireret af den parlamentariske styringskæde, tilpasset til en kommunal kontekst. Hvad angår forholdet mellem det kommunale og nationale demokrati, har et temanummer i Politica set nærmere på rammevilkårene for kommunernes virke (Udhuling af lokaldemokratiet, Politica nr. 2/2010); og Kjær og Elklit (2010) har undersøgt graden af nationalisering af de kommunale. Hvad angår det kommunale politiske system, har en række studier undersøgt kommunalpolitikeres repræsentation, motivation, indflydelse, holdninger og vilkår (Dahlgaard og Pedersen 2010; Jakobsen og Kjær, 2015; Kjær, Hjelmar og Olsen 2010; og temanummeret i Økonomi og Politik nr. 4/2013), politisk konsensus i kommunalbestyrelserne (Houlberg og Pedersen 2014), 
og organiseringen af de kommunale politiske systemer (Bækgaard 2008). Hansen et al. (2008) undersøger organiseringen af forvaltningen i kommunerne, og to studier har også set på oprettelsen af borgerservicecentre i de sammenlagte kommuner (Bhatti, Olsen og Pedersen 2011) samt ændringer i skolestrukturen i kommunerne (Bækgaard 2010).

Figur 2 Det kommunale demokrati

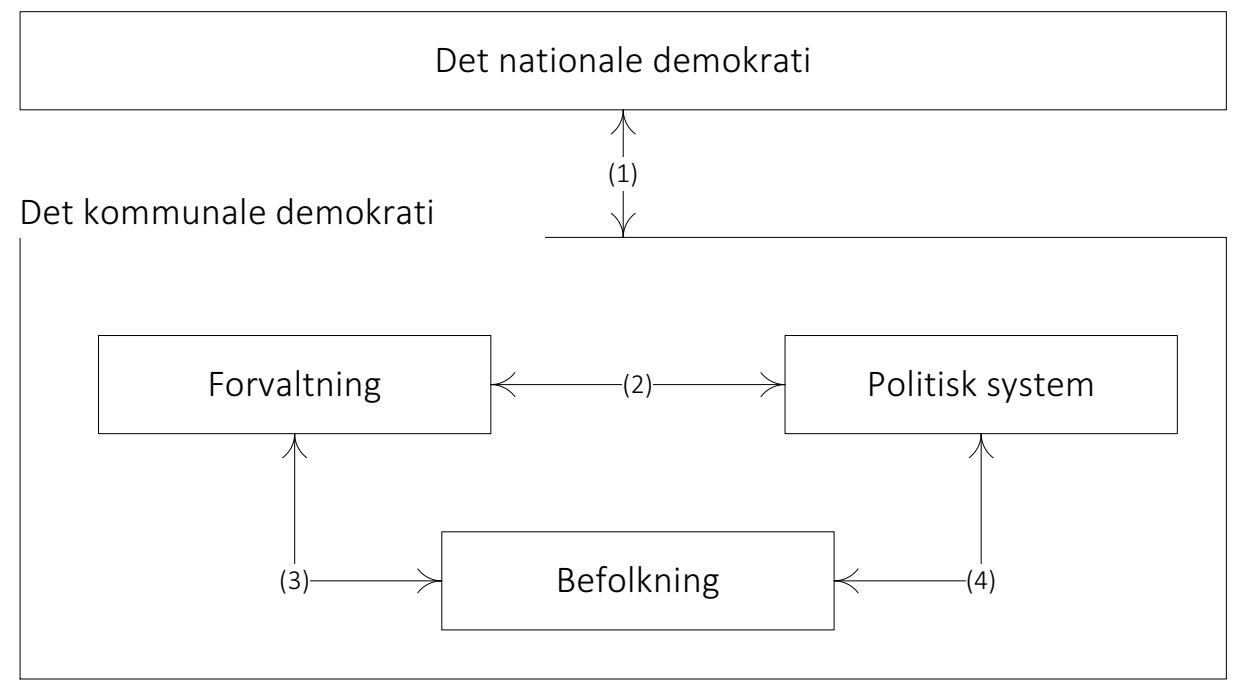

Udover disse studier er der også en række effektstudier af borgerne og deres relation til det politiske system, og til dels også forvaltningen, som undersøger hvordan Strukturreformen påvirkede borgernes lokalpolitiske meninger, holdninger og adfærd. Et fællestræk ved disse nylige studier er, at man interesserer sig for ét centralt aspekt ved sammenlægningerne: Forøgelsen af indbyggertallet, der $\mathrm{i}$ sagens natur følger af at blive sammenlagt. Dette skyldes, at man i den eksisterende litteratur har interesseret sig meget for kommunernes befolkningsmæssige størrelse og dets betydning for lokaldemokratiet (se særligt Kjær og Mouritzen 2003; og Denters et al. 2014). Sammenlægningerne er dermed blevet anvendt til at undersøge et mere generelt spørgsmål om sammenhængen mellem størrelsen på politiske systemer og demokratiets tilstand, eller kvalitet om man vil (et hovedværk er her Dahl og Tufte 1973). ${ }^{18}$

\footnotetext{
${ }^{18}$ Det er ikke naturgivent hvad man forstår ved størrelsen på et politisk system. Ofte defineres det som den befolkningsmæssige størrelse, men andre relaterede aspekter er geografisk størrelse (areal), befolkningstæthed og urbaniseringsgrad (Dahl og Tufte 1973: 17). Når man i forskningen overvejende har valgt at fokusere på førstnævnte snarere end dem alle skyldes det blandt andet det forhold, at der ofte er en stærk sammenhæng mellem disse karakteristika; og formentlig også det forhold at det er muligt at ændre den befolkningsmæssige størrelse på kommuner, hvilket i mindre grad er tilfældet for de andre. For man får ikke en bykommune ud af at sammenlægge fem landkommuner (reformulering af Houlberg og Larsen 2000: 32).
} 
Et første spørgsmål er her, hvordan man i disse studier har begrebsliggjort lokaldemokratiet. Først og fremmest, hvad der bør kendetegne et demokrati - nationalt og lokalt - er der på ingen måder enighed om. Og i denne artikel vil der ikke blive redegjort nærmere for de forskellige normative forståelser af demokratiet som en styreform. For at indfange den litteratur, som reviewes her, er det nødvendigt med et relativt bredt demokratibegreb som en styreform, der er i stand til at efterleve to sæt af kriterier: De substantive og de procedurale. Et demokrati skal være i stand til at levere ydelser, som stemmer overens med befolkningens præferencer, og det skal også give borgerne indflydelse på det politiske systems beslutninger (Dahl og Tufte 1973; Kjær og Mouritzen 2003, Denters et al. 2014). Hvor velfungerende et demokrati er, er derfor et spørgsmål med mange dimensioner, der - for blot at nævne nogle få - vedrører borgernes evne til at deltage i politik, hvor meget de deltager, deres tillid til de folkevalgte og hvor tilfredse de er med de leverede ydelser. Til disse politiske kompetencer, orienteringer og til adfærd tilføjer man ofte også sociale orienteringer og adfærd (herunder om man har tillid til sine medmennesker, deltagelse i foreningsliv, og om man identificerer sig med og føler sig tilknyttet til fællesskabet), der så at sige kommer før de substantive og procedurale kriterier: At borgerne opfatter sig selv som en del af fællesskabet. Dermed bliver en vurdering af et demokratis tilstand også et spørgsmål om, hvorvidt der eksisterer et fællesskab. Da genstandsområdet i denne artikel er kommunerne, skal disse dimensioner selvsagt forstås i en kommunal kontekst.

Dette bringer os til spørgsmålet om, hvorfor og hvordan størrelsen på et politisk system påvirker demokratiets tilstand. I og med at demokrati er et bredt begreb, har eksisterende studier af de forskellige dimensioner også gjort brug af forskellige forklaringer på sammenhængen. Men to bredt dækkende forklaringer, som en del studier gør brug af, argumenterer for, at størrelse kan have henholdsvis en negativ og en positiv indvirkning på demokratiet (Dahl og Tufte 1973; Denters et al. 2014; Verba og Nie, 1972). I kondenseret form er argumenterne følgende: På den ene side argumenterer 'decline of community'-modellen for, at den sociale sammenhængskraft er stærkere i mindre demokratier, hvilket også giver udslag i borgernes politiske orienteringer (såsom deres politiske interesse) og deres politiske adfærd. På den anden side argumenterer mobiliserings-modellen for, at større demokratier er kendetegnet ved større social og politisk diversitet, hvilket vil virke fremmende for borgernes interesse for og viden om politik, ligesom det vil øge det politiske systems lydhørhed over for borgerne. Endelig kan man for det tredje fremhæve en alternativ forklaring om, at størrelse ikke har nogen indvirkning på demokratiet, ud fra et argument om at størrelse samvarierer med andre karakteristika, som påvirker demokratiet, hvor der særligt tænkes på individkarakteri- 
stika. Med andre ord kan det være, at observerede forskelle i lokaldemokratiets tilstand blandt kommuner af forskellig størrelse skyldes forskelle i befolkningssammensatningen i disse kommuner, snarere end at det skyldes størrelsen. Denne tredje forklaring er af metodisk karakter, som vedrører næste spørgsmål.

Det tredje spørgsmål er, hvordan studier af sammenlægningerne i 2007 kan bidrage til den eksisterende litteratur. Relationen mellem størrelsen på politiske systemer og demokratiets tilstand var i forvejen undersøgt over tidsperioder, hvor der ikke blev gennemført sammenlægninger (i en dansk kontekst er hovedværket Kjær og Mouritzen 2003; og et nyligt udgivet større komparativt studie er Denters et al. 2014). Så hvad vindes der ved også at studere sammenhængen i forbindelse med sammenlægningerne i 2007? Svaret er, at sammenlægninger under nogle omstændigheder kan betragtes som kvasi-eksperimenter, der gør det muligt at estimere mere troværdige kausale effekter af sammenhængen mellem kommunestørrelse og lokaldemokratiets tilstand (og andre lokale forhold, for den sags skyld). Det afgørende er her, om sammenlægningerne kan betragtes som eksogene, således at man kan udelukke bias fra revers kausalitet og tredjevariable. Førstnævnte er en klassisk problemstilling inden for politologien (og samfundsvidenskaben mere generelt), der vedrører, om den kausale retning nu også kun går fra den uafhængige til den afhængige variabel - eller om der også kan være en påvirkning i den modsatte retning. For nærværende er en sådan revers kausalitet en reel mulighed, da det ikke kan betragtes som tilfældigt, hvor man vælger at bosætte sig. Dermed opstår der det problem, at en observeret forskel i lokaldemokratiets tilstand mellem kommuner af forskellig størrelse ikke kun vil kunne tilskrives forskelle i størrelse, men potentielt også at borgerne bosat i kommunerne har forskellige lokaldemokratiske præferencer. Kommunesammenlægninger ændrer jo ikke noget ved dette grundlæggende problem, men de kan alligevel medvirke til at "ensrette" den kausale retning, hvis det er plausibelt, at sammenlægningerne i sig selv er eksogene. Dette indebærer, at borgerne bosat i kommunerne ikke kunne påvirke, om deres kommune blev sammenlagt eller ej. For hvis dette er tilfældet, er det muligt at betragte stigningerne i kommunestørrelse (som følger af at blive sammenlagt) som eksogene (for en mere udførlig beskrivelse, se for eksempel Hansen og Hjelmar 2015; og Lassen og Serritzlew 2011; og en mere generel indføring i eksperimentelle designs gives af for eksempel Blom-Hansen og Serritzlew 2014).

Et andet klassisk problem er bias fra udeladte tredjevariable, hvilket i forbindelse med sammenlægninger kan komme til udtryk ved, at det jo ikke er tilfældigt om man bliver sammenlagt eller ej, eller hvem man bliver sammenlagt med (se herom Bhatti og Hansen 2011). Den traditionelle løsning på denne manglende tilfældighed er statistisk kontrol, men denne tilgang har selvsagt den be- 
grænsning, at man skal kunne observere disse variable for at kunne holde dem konstante. En anden løsning på sammenlægningernes manglende tilfældighed er at bruge en før-måling til at justere for initiale forskelle mellem kommuner som oplever forskellige stigninger i størrelse, og på den måde tage højde for tredjevariable - både observerbare variable (på individ- eller kommuneniveau) såvel som uobserverbare tidskonstante variable (for mere om sidstnævnte, se for eksempel Wooldridge, 2009: 462ff). Denne løsning må siges at være den stærkeste af de to, og er da også blevet anvendt $\mathrm{i}$ mange af de nylige studier af sammenlægningerne i 2007.

I Tabel 3 gives en oversigt af studier der har undersøgt borgernes politiske meninger, holdninger og adfærd (samt sociale orienteringer) i forbindelse med sammenlægningerne i $2007 .{ }^{19}$ Som det fremgår, er der blevet undersøgt et bredt sæt af dimensioner i lokaldemokratiets tilstand, som spænder fra sociale orienteringer (om man er aktiv i det lokale foreningsliv, og den følte/affektive tilknytning til kommunen) over procedurale kriterier, der omfatter evnen til at deltage i lokalpolitik (politisk effektivitetsfølelse), interessen for lokalpolitik og tilliden til lokalpolitikerne, til tilfredsheden med lokaldemokratiet og deltagelse i kommunalvalg samt substantive kriterier som tilfredshed med lokale serviceydelser og faciliteter.

For det første er det kendetegnende for mange af studierne, at kommunesammenlægningerne studeres ud fra et argument om kommunestørrelsens betydning for lokaldemokratiets tilstand (undtagelserne er her Jakobsen 2009; og Kjær og Klemmensen 2014). Det er dog forskelligt, hvordan man måler ændringen i størrelse i disse studier: I dem alle anvendes en dikotomi mellem borgere bosat i sammenlagte og borgere bosat i fortsættende (altså ikke sammenlagte) kommuner. Dette er et ret groft mål for stigningen i indbyggertallet, og derfor anvender nogle af studierne også mere finkornede mål. Disse baserer sig på en yderligere opdeling af de sammenlagte kommuner, på den absolutte eller relative stigning i indbyggertallet som følge af at blive sammenlagt, eller hvor der tages højde for indbyggertallet før sammenlægningen (Hansen 2013 og 2015; Hansen og Hjelmar 2015; Lassen og Serritzlew 2011). Udover at være et mere direkte mål for stigningen i indbyggertallet, har de sidstnævnte af disse mål også den fordel, at man bedre kan isolere effekten af stigningen i indbyggertallet fra de andre effekter, som det at blive sammenlagt kan have på lokaldemokratiet (herunder harmoniseringen af serviceniveauer og den politiske og administrative reorganisering $i$ forbindelse med sammenlægninger).

\footnotetext{
${ }^{19}$ Oversigten er afgrænset, så der kun medtages publicerede studier af kommunesammenlægningerne i 2007 (og dermed er der blandt andet udeladt working papers, konference-papers og specialer), som er udgivet i artikelform i akademiske tidsskrifter, og med de kommunale vælgerbefolkninger som population.
} 
Tabel 3 Effektstudier af borgernes politiske meninger/holdninger/adfærd og sammenlægningerne i 2007

\begin{tabular}{|c|c|c|c|c|}
\hline Studie & Dimensioner, $Y$ & Data & Estimation & Resultater \\
\hline Bhatti og Hansen (2010) & Valgdeltagelse & $\begin{array}{l}\text { Registerdata, tværsnit (2009) } \\
\text { på individniveau og panel på } \\
\text { kommuneniveau (1997- } \\
\text { 2009) }\end{array}$ & $\begin{array}{l}\text { OLS og logistisk regression, } \\
\text { Statistisk kontrol for tredje } \\
\text { variable }\end{array}$ & $\begin{array}{l}\text { Tvetydige, men hovedanalyse viser } \\
\text { lidt lavere valgdeltagelse i sammen- } \\
\text { lagte kommuner }\end{array}$ \\
\hline Hansen (2013) & $\begin{array}{l}\text { Politisk tillid (herunder eks- } \\
\text { tern politisk effektivitetsfø- } \\
\text { lelse) }\end{array}$ & $\begin{array}{l}\text { Surveydata }{ }^{1} \text {, panel (2001- } \\
2009)\end{array}$ & $\begin{array}{l}\text { OLS, difference-in- } \\
\text { differences }\end{array}$ & $\begin{array}{l}\text { Moderat negativ sammenhæng mel- } \\
\text { lem relativ stigning i indbyggertal og } \\
\text { politisk tillid (skyldes særligt lyd- } \\
\text { hørhed/ekstern politisk effektivitets- } \\
\text { følelse) }\end{array}$ \\
\hline Hansen (2015) & $\begin{array}{l}\text { Tilfredshed med lokaldemo- } \\
\text { kratiet, lokale serviceydelser, } \\
\text { lokale faciliteter og hvor godt } \\
\text { kommunen håndterer lokale } \\
\text { problemer }\end{array}$ & $\begin{array}{l}\text { Surveydata }^{1} \text {, panel (2001- } \\
2009)+ \text { tværsnit (2009) }^{-1}\end{array}$ & $\begin{array}{l}\text { OLS, difference-in- } \\
\text { differences }\end{array}$ & $\begin{array}{l}\text { Svag-moderat negativ sammenhæng } \\
\text { mellem relativ stigning i indbygger- } \\
\text { tal og tilfredshed med lokaldemokra- } \\
\text { tiet og serviceydelser samt evne til at } \\
\text { håndtere lokale problemer }\end{array}$ \\
\hline Hansen og Hjelmar (2015) & $\begin{array}{l}\text { Aktiv i foreningsliv, affektiv } \\
\text { tilknytning, intern og ekstern } \\
\text { politisk effektivitetsfølelse, } \\
\text { politisk interesse, politisk }\end{array}$ & $\begin{array}{l}\text { Surveydata }^{1} \text {, tre uafhængige } \\
\text { tværsnit }(2001,2009,2013)\end{array}$ & $\begin{array}{l}\text { OLS, difference-in- } \\
\text { differences }\end{array}$ & $\begin{array}{l}\text { Svag negativ sammenhæng mellem } \\
\text { relativ stigning i indbyggertal og } \\
\text { affektiv tilknytning, og til dels intern } \\
\text { politisk effektivitetsfølelse (hvor }\end{array}$ \\
\hline
\end{tabular}

\footnotetext{
${ }^{1}$ Disse survey-data er selvsagt nødvendigvis blevet kombineret med registerdata på blandt andet om kommuner blev sammenlagt eller ej, og indbyggertal.
} 


\begin{tabular}{|c|c|c|c|c|}
\hline Studie & Dimensioner, $Y$ & Data & Estimation & Resultater \\
\hline & tillid, valgdeltagelse & & & $\begin{array}{l}\text { godt man føler sig informeret) og } \\
\text { politisk tillid/ekstern politisk effekti- } \\
\text { vitetsfølelse (lydhørhed) }\end{array}$ \\
\hline Jakobsen (2009) & Lokal stemmeadfærd & Registerdata, tværsnit (2005) & Multilevel-analyse & $\begin{array}{l}\text { Større lokal stemmeadfærd i sam- } \\
\text { menlagte kommuner }\end{array}$ \\
\hline Kjær og Klemmensen (2014) & $\begin{array}{l}\text { Vælgertilslutning til borgme- } \\
\text { sterparti }\end{array}$ & $\begin{array}{l}\text { Registerdata og surveydata, } \\
\text { tværsnit (2009) }\end{array}$ & $\begin{array}{l}\text { OLS og (multilevel) logitisk } \\
\text { regression, statistisk kontrol } \\
\text { for tredje variable }\end{array}$ & $\begin{array}{l}\text { Lavere vælgertilslutning til borgme- } \\
\text { sterpartier i sammenlagte kommuner }\end{array}$ \\
\hline Lassen og Serritzlew $(2011)^{2}$ & $\begin{array}{l}\text { Intern politisk effektivitetsfø- } \\
\text { lelse }\end{array}$ & $\begin{array}{l}\text { Surveydata }{ }^{1} \text {, to uafhængige } \\
\text { tværsnit }(2001,2007 / 2008)\end{array}$ & $\begin{array}{l}\text { OLS, difference-in- } \\
\text { differences og matching }\end{array}$ & $\begin{array}{l}\text { Moderat-stærk negativ sammenhæng } \\
\text { mellem stigning i indbyggertal og } \\
\text { intern politisk effektivitetsfølelse }\end{array}$ \\
\hline Nielsen og Vestergaard (2014) & $\begin{array}{l}\text { Ekstern politisk effektivitets- } \\
\text { følelse }\end{array}$ & Surveydata $^{1}$, tværsnit (2009) & $\begin{array}{l}\text { Multilevel-analyse, statistisk } \\
\text { kontrol for tredje variable }\end{array}$ & $\begin{array}{l}\text { Negativ sammenhæng mellem ind- } \\
\text { byggertal (ln) og ekstern politisk } \\
\text { effektivitetsfølelse }\end{array}$ \\
\hline
\end{tabular}

\footnotetext{
${ }^{2}$ To nært forbundne studier er Lassen og Serritzlew (2010) og KREVI (2009).
} 
For det andet baserer alle studierne sig hovedsageligt på survey-data med nogle få undtagelser: Bhatti og Hansen (2010), som undersøger borgernes valgdeltagelse ved hjælp af registerdata på kommune- og individniveau. Endvidere er der dele af analyserne i flere af de andre studier, som baserer sig på registerdata på kommuneniveau, herunder data fra kommunalvalgene. Det er selvsagt nødvendigt at gøre brug af survey-data for at undersøge mange af dimensionerne i lokaldemokratiet, da der ikke eksisterer registerdata på dem. ${ }^{1}$ Men der er velkendte problemer med målefejl i surveydata, herunder social desirability bias (at man svarer i retning af, hvad der er socialt forventeligt) og hukommelsesfejl, som kan undgås ved i stedet at gøre brug af registerdata (mere kan læses herom i for eksempel Hansen, 2012). Når dette altså er muligt som i Bhatti og Hansens tilfælde, undgår de blandt andet de velkendte problemer med overrapportering af valgdeltagelse i surveys.

Det er for det tredje også forskelligt, hvordan studierne adresserer bias fra revers kausalitet og tredjevariable. Nogle er traditionelle tværsnitsanalyser, hvor der kontrolleres for et sæt af observerbare karakteristika på individ- og kommuneniveau, mens andre gør brug af data med tidlig variation, paneldata eller flere uafhængige tværsnit, hvor der opnås en stærkere kontrol for tredjevariable, som uddybet tidligere. En række af studierne benyttes sig af den såkaldte differences-in-differences identifikationsstrategi (se for eksempel Meyer 1995), der udnytter denne tidslige variation til at kontrollere for initiale forskelle mellem kommuner, der oplever forskellige stigninger i størrelse - og som på den måde er i stand til at kontrollere for ikke kun observerbare variable, men også uobserverbare tidskonstante variable på kommuneniveau. (Og for paneldata kan man hertil tilføje, at man også kan kontrollere for sidstnævnte på individniveau).

Hvad viser studierne så for sammenhængen mellem kommunestørrelse og lokaldemokratiets tilstand? Som det fremgår af Tabel 3, finder næsten alle studier en negativ sammenhæng, således at de pågældende dimensioner af lokaldemokratiet svækkes, når kommunens indbyggertal stiger. Bhatti og Hansen (2010) undersøger kommunal valgdeltagelse på registerdata på kommuneniveau for valgene 1997-2009, og på registerdata på individniveau i 2009 - og dermed på kort sigt, to år efter sammenlægningernes ikrafttræden. De foretager en række analyser af niveauer af valgdeltagelse i forskellige år og ser også på ændringer i valgdeltagelse mellem valg - begge med statistisk kontrol med tredjevariable. De har derfor et metodisk svagere design i forhold til flere af de andre studier, om end det samtidigt skal nævnes, at det er en fordel, at en del af deres analyse baserer sig på registerdata på individniveau. Deres resultater er tvetydige, men de finder indikationer på et mindre fald i valgdeltagelsen i de kommuner, som blev sammenlagt - to år efter sammenlægningerne blev

\footnotetext{
${ }^{1}$ Det skal dog her bemærkes, at survey-dataene nødvendigvis må suppleres med registerdata på kommuneniveau jf. note til Tabel 3.
} 
gennemført. I forlængelse heraf undersøger Jakobsen (2009) lokal stemmeadfærd (hvormed der menes, om vælgere stemmer på kandidater fra deres eget lokalområde). Det undersøger han ved hjælp af et komparativt casestudie samt statistiske analyser på et tværsnitsdatasæt fra $2005^{2}$, der baserer sig på oplysninger om lokalområder fra udvalgte fortsættende kommuner og næsten alle de sammenlagte kommuner. Jakobsen finder belæg for, at sammenlægningerne har forstærket tendensen til at stemme lokalt ved kommunalvalg.

Hansen (2013) bruger differences-in-differences på et panel baseret på to surveys til at undersøge, om borgernes tillid til lokalpolitikerne (målt som borgernes vurdering af politikernes kompetence og integritet samt deres lydhørhed over for borgerne) blev påvirket af stigningerne i kommunestørrelse som følge af sammenlægningerne på kortere sigt (i og med at eftermålingen er foretaget cirka to år efter sammenlægningerne). Han finder belæg for en moderat, negativ effekt af stigning $i$ størrelse på tillid (som kan tilskrives lydhørhed men ikke integritet eller kompetence). Hansen (2015) bruger samme datasæt, samt et uafhængigt tværsnit fra 2009, til at undersøge tilfredshed med forskellige input- og outputmål (lokaldemokratiet samt kommunal service og faciliteter og evne til at håndtere problemer), og finder en svag til moderat negativ effekt af stigning i størrelse på disse mål undtagen et af dem (tilfredshed med faciliteter). Hansen og Hjelmar (2015) gør ligeledes brug af differences-in-differences, men på et puljedatasæt bestående af tre uafhængige tværsnit (fra henholdsvis 2001, 2009 og 2013), og undersøger et bredt sæt af dimensioner i lokaldemokratiet. Dette er det eneste af studierne, der både undersøger de kortere- og længeresigtede effekter af stigningerne i størrelse (i 2009 og 2013, altså to og seks år efter sammenlægningerne). De finder belæg for en svag negativ effekt af stigning i størrelse på henholdsvis borgernes følte tilknytning til deres kommune på kortere og længere sigt, til dels intern politisk effektivitetsfølelse (kun indikatoren for hvor godt man føler sig informeret) på kortere sigt, og til dels politisk tillid/ekstern politisk effektivitetsfølelse (kun indikatoren for lydhørhed) på kortere og længere sigt. Den interne politiske effektivitetsfølelse undersøges også af Lassen og Serritzlew, der gør brug af et bredere sæt af indikatorer end førnævnte, og som benytter sig af differences-in-differences og matching på et puljedatasæt bestående af to uafhængige tværsnit fra henholdsvis 2001 og 2007/2008. De ser dermed på den meget kortsigtede effekt ét år efter sammenlægningernes gennemførsel, og finder - med deres meget stærke design - en moderat til stærk negativ effekt af stigning i indbyggertal på intern effektivitetsfølelse.

\footnotetext{
${ }^{2}$ Som var det første kommunalvalg til kommunalbestyrelserne for de nye sammenlagte kommuner, og som derfor blev afholdt godt et år før sammenlægningerne trådte i kraft.
} 
Nielsen og Vestergaard (2014) undersøger ekstern politisk effektivitetsfølelse (lydhørhed), hvor de gør brug af et bredere sæt af indikatorer end både Hansen (2013) og Hansen og Hjelmar (2015), og deres analyser baserer sig på et tværsnit fra 2009 (multilevelanalyse med statistisk kontrol for tredjevariable), hvorfor deres studie er metodisk svagere i forhold til de førnævnte. De finder, at indbyggertal (logaritmisk transformeret) har en negativ effekt på den eksterne effektivitetsfølelse i 2009, men dette siger ikke noget direkte om, hvorvidt stigningerne i størrelse som følge af sammenlægningerne har påvirket effektivitetsfølelsen - men blot at der to år efter sammenlægningerne er en negativ sammenhæng mellem førnævnte variable. Endelig er der Kjær og Klemmensen (2014), der ved hjælp af registerdata på kommuneniveau og en survey fra 2009 undersøger vælgernes tilslutning til borgmesterpartiet. De finder, at tilslutningen er lavere i de sammenlagte kommuner.

Hvad er så den overordnede konklusion? Det er selvsagt ikke uden vanskeligheder at formulere en sådan, i og med at lokaldemokratiet har så mange dimensioner - og i og med at det ikke er naturgivent, hvornår forskelle i lokaldemokratiets tilstand i kommunerne er så store, at de må betragtes som problematiske. Men ser vi på tværs af studierne, så er det et fællestræk for dem, at man finder negative effekter, således at stigninger i størrelse svækker demokratiets tilstand. Her skal det dog samtidigt bemærkes, at effekterne typisk er svage til moderate i styrke. Disse resultater stemmer overens med den eksisterende litteratur, hvor man typisk også har fundet negative sammenhænge, men som ofte ikke er særligt stærke (Kjær og Mouritzen 2003; Denters et al. 2014). ${ }^{3}$ Det skal i den forbindelse også bemærkes, at studierne anlægger en ekstensiv analysestrategi og dermed undersøger lokaldemokratiets tilstand ved hjælp af gennemsnitsbetragtninger på tværs af mange af landets kommuner - ofte dem alle eller i hvert fald de fleste af dem. Og konklusionen skal læses i dette lys.

Her skal man selvsagt også have in mente, at spørgsmålet om sammenhængen mellem kommunestørrelse og lokaldemokratiets tilstand ikke er blevet endeligt besvaret i en dansk - eller international - kontekst. Forbundet hermed er, at selvom føromtalte studier af sammenlægningerne i 2007 har vigtige metodiske fordele over tidligere studier, så er det samtidigt ikke uproblematisk at anvende kommunesammenlægninger til at studere sammenhængen mellem størrelse og demokrati. Også selvom sammenlægningerne giver overordentligt gode muligheder for at undersøge sammen-

\footnotetext{
${ }^{3}$ I forbindelse hermed skal man endvidere huske på, at kun en mindre andel af den danske befolkning har oplevet store stigninger i deres kommunes indbyggertal i forbindelse med sammenlægningerne i 2007. Langt størstedelen af landets borgere oplevede ingen - eller relativt små - stigninger. Hvilket man skal have in mente i fortolkningen af resultaterne i de studier som finder moderat til stærke effekter.
} 
hængen mellem kommuners størrelse og lokaldemokratiets tilstand. I det følgende vil jeg beskrive nogle af de centrale udfordringer, som vi står tilbage med.

\section{Hvad ved vi stadig mindre om?}

Som beskrevet tidligere er der nogle metodiske fordele forbundet med at anvende kommunesammenlægningerne i 2007 til at undersøge sammenhængen mellem størrelsen på politiske systemer og demokratiets tilstand: At vi kan estimere mere troværdige kausale effekter af sammenhængen mellem førnævnte. Dette er dog en forsimpling, som skal nuanceres. For det første var Strukturreformen en meget omfattende reform, som ændrede flere kommunale (og regionale) forhold samtidigt; og det rejser naturligvis spørgsmålet om, hvorvidt man kan isolere effekten af stigningerne i kommunernes befolkningsmæssige størrelse fra disse andre forhold, herunder den potentielle effekt som andre aspekter af sammenlægningerne kan have haft. Som beskrevet tidligere har en række af studierne prøvet at adressere dette, men spørgsmålet er, hvor godt det er lykkedes. Det kan vi selvsagt ikke vide med sikkerhed, hvilket understreger, at sammenlægninger nok kan give bedre vilkår for at undersøge betydningen af størrelse, men ingenlunde perfekte vilkår.

Forbundet hermed er for det andet det forhold, at studierne jo kun undersøger lokaldemokratiets tilstand på tilfælde, hvor kommunernes befolkningsmæssige størrelse stiger. For sammenlægninger medfører i sagens natur kun stigninger i indbyggertallet, ikke fald. Men hvad sker der så med lokaldemokratiet, når befolkningstallet falder i kommunerne? Det er jo en tendens, som vi ser i flere landsdele i dag, og som vi har set over en længere årrække, hvorfor der er tale om et spørgsmål med høj aktuel relevans. Problemstillingens omfang er illustreret i Figur 3, hvor man kan se, at der over den 25-årige periode fra 1979 til 2003 er sket betragtelige befolkningsændringer i nogle af landets kommuner: Fra fald i indbyggertallet på op mod 20-25 procent (i de tidligere Ravnsborg, Ærøskøbing og Sydlangeland Kommuner) til stigninger på 40-50 procent (Jægerspris, Græsted-Gilleleje og Grundsø Kommuner). Desværre kan vi ikke bruge studierne af sammenlægningerne i 2007 til at besvare førnævnte spørgsmål med, for det ville svare til ekstrapolering ${ }^{4}$, hvorfor spørgsmålet stadig forbliver ubesvaret.

\footnotetext{
${ }^{4}$ Udtrykt i forhold til Figur 3 svarer ekstrapolering til, at man udtaler sig om konsekvenserne af fald i indbyggertal (variationen til venstre for nullet) på baggrund af analyser af konsekvenserne af stigninger i indbyggertal (variationen til højre for nullet).
} 


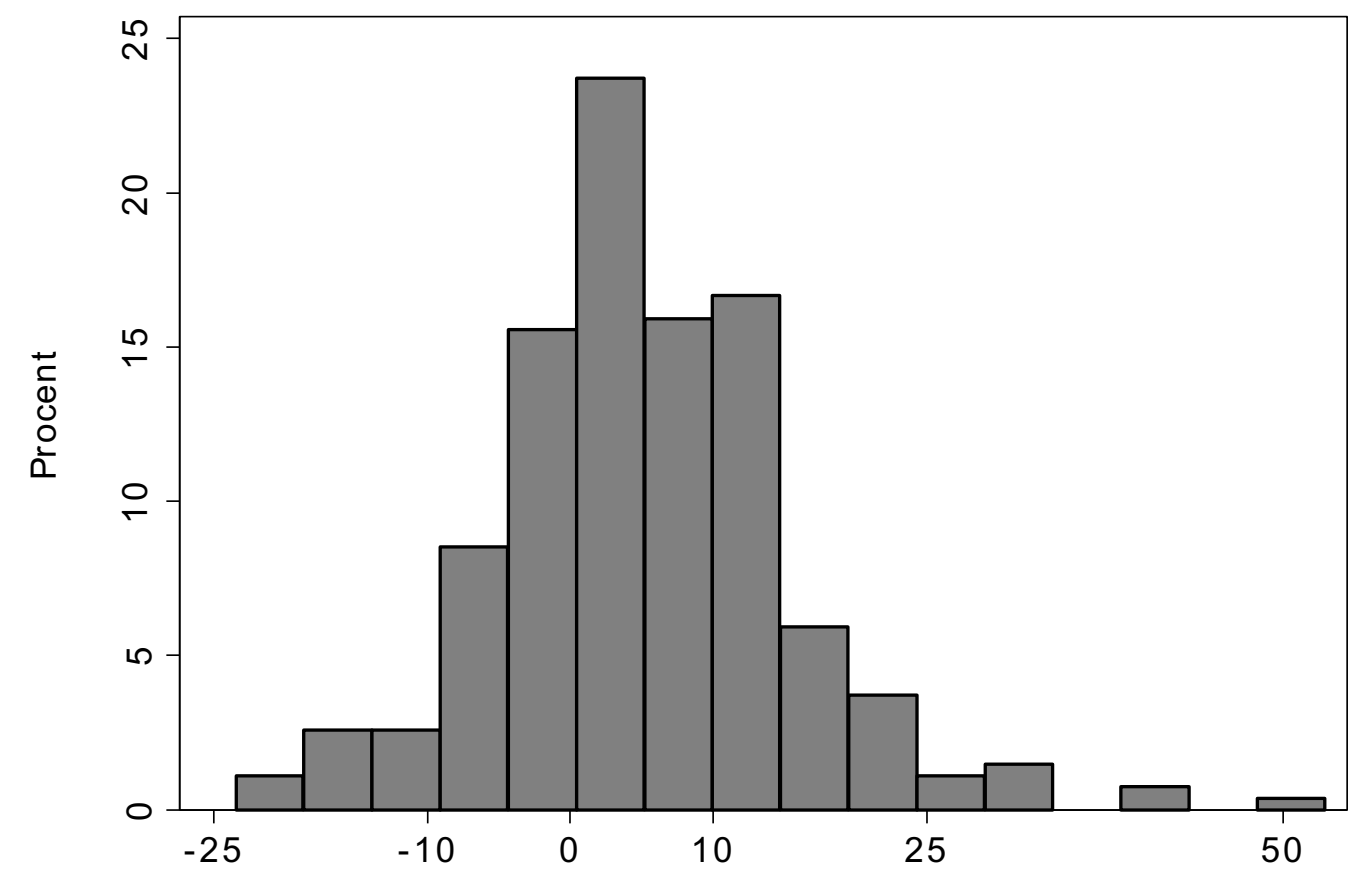

Kilde: Danmarks Statistik Statistikbanken tabel BEF1A.

For det tredje er der spørgsmålet om, hvorvidt de fundne effekter af sammenlægningerne i 2007 er udtryk for kortsigtede effekter, som måske retter sig over en årrække - eller om der i stedet er tale om mere langsigtede effekter, som har en mere blivende karakter. Først og fremmest er det generelt sværere at undersøge langsigtede effekter, blandt andet fordi kommunerne kan tænkes at reagere på eventuelle lokaldemokratiske problemer - og fordi betydningen af andre forhold udover sammenlægningerne må forventes at blive større og større over tid. Med dette in mente så er det stadig ikke et spørgsmål, som er blevet undersøgt særligt meget i en dansk (eller international) kontekst, hvilket også fremgår af Tabel 3; næsten alle studierne gør brug af data, som er indsamlet indenfor et par år efter sammenlægningerne trådte i kraft. Kun et enkelt af studierne, Hansen og Hjelmar (2015), har på nuværende tidspunkt undersøgt de længeresigtede konsekvenser af sammenlægningerne, seks år efter sammenlægningernes ikrafttræden. Der vil formentlig komme flere længeresigtede studier af kommunesammenlægningerne i 2007, så vi bliver nok klogere på spørgsmålet i de kommende år.

Spørgsmålet er, hvor godt de omtalte studier rejser over tid og sted. De særlige omstændigheder, der opstår i forbindelse med reformer, og som sætter os i stand til at estimere mere troværdige effekter, kan paradoksalt nok samtidigt gøre det svært at generalisere til andre omstændigheder. Dette blev allerede berørt ovenfor i forbindelse med overvejelserne om ekstrapolering, men et yderligere 
problem er følgende: En stigning i indbyggertallet som følge af en sammenlægning indtræder jo meget pludseligt - og kan af den grund også tænkes at have en stærkere effekt, end hvis stigningen var sket mere gradvist over en længere årrække. Problemet er, at ændringer i kommunernes indbyggertal som oftest netop sker gradvist snarere end pludseligt, hvilket også fremgår af Figur 4. Her ser vi, at de årlige ændringer i kommunernes indbyggertal typisk er meget små (for de midterste 50 procent mellem -3 og +4 procent pro anno, over den 25-årige tidsperiode fra 1979 til 2003). Men mange bække små, som man siger - hvilket også fremgår af Figur 3, hvor vi ser, at den aggregerede stigning i indbyggertallet over de 25 år er ganske stor for nogle kommuner. Ville vi forvente at observere de samme ændringer i lokaldemokratiets tilstand i disse kommuner, som vi observerer for de pludselige befolkningsstigninger af samme størrelsesorden i forbindelse med sammenlægningerne? Vi har ikke grundlag for en sådan forventning, og derfor er der også her et ubesvaret spørgsmål. Men det er også et spørgsmål, som det vil være meget svært at besvare, i og med at der er netop tale om mindre gradvise ændringer over tid.

Figur 4 Årlige ændringer i kommunernes indbyggertal, 1979-2003 (\%)

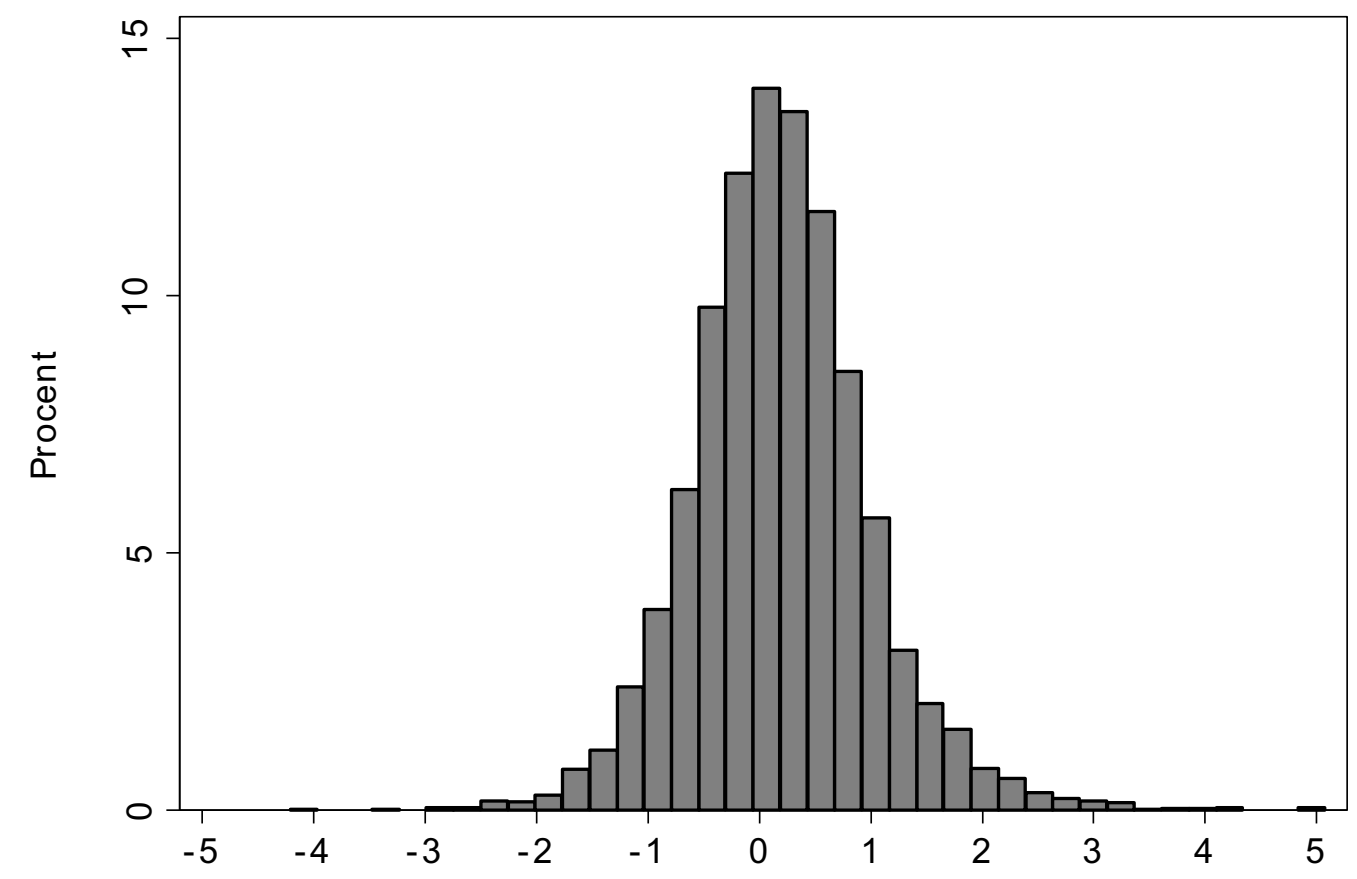

Kilde: Danmarks Statistik Statistikbanken tabel BEF1A.

Med alt dette i mente, hvad er bundlinjen så? Som det tidligere blev fremført, så er den samlede konklusion, at resultaterne fra studierne, der har anvendt sammenlægningerne til at studere sam- 
menhængen mellem størrelsen på politiske systemer og demokratiets tilstand, stemmer overens med den eksisterende litteratur, der har påvist nogle negative sammenhænge. Det er konsistent med 'decline of community'-modellen, om end sammenhængene ofte ikke er særligt stærke. Selvom der er nuancer til denne hovedkonklusion, så står det i hvert fald klart, at borgernes lokaldemokratiske meninger, holdninger og adfærd bestemmes af mange andre faktorer end størrelsen på kommunen. Som tidligere forskning har vist, er det særligt karakteristika på individniveau, som er vigtige (Kjær og Mouritzen 2003; og Denters et al. 2014). Med andre ord er det i mindre grad størrelsen på fællesskabet, der har betydning for lokaldemokratiets tilstand, og i højere grad karakteristika ved individerne, som indgår i fællesskabet. Så ser man forskelle på lokaldemokratiets tilstand i små og større kommuner, skyldes det mere forskelle i, hvem der har valgt at bosætte sig i disse kommuner, end det skyldes størrelsen.

\section{Litteratur}

Bhatti, Y og K M Hansen 2010, 'Kommunalreformens betydning for den kommunale valgdeltagelse', Tidsskriftet Politik, vol. 13, no. 3, pp. 6-16.

Bhatti, Y og K M Hansen 2011, 'Who 'marries' whom? The influence of societal connectedness, economic and political homogeneity, and population size on jurisdictional consolidations', European Journal of Political Research, vol. 50, no. 2, pp. 212-238.

Bhatti, Y, A L Olsen og L H Pedersen 2011, 'Keeping the Lights On: Citizen Service Centers in Municipal Amalgamations', Administration in Social Work, vol. 35, no. 1, pp. 3-19.

Blom-Hansen, J, J Elklit og S Serritzlew (red.) 2006, Kommunalreformens konsekvenser, Academica, Aarhus.

Blom-Hansen, J og S Serritzlew 2014, 'Endogenitet og eksperimenter - forskningsdesignet som løsning', Politica, vol. 46, no. 1, pp. 5-23.

Buch, Roger og J Elklit (red.) 2007, Nye kommunalvalg? Kontinuitet og forandring ved valget $i$ 2005. Syddansk Universitetsforlag, Odense.

Bækgaard, M 2008, 'Politisk og administrativ organisering i danske kommuner: Strukturreformens betydning', Politica, vol. 40, no. 3, pp. 349-368.

Bækgaard, M 2010, 'Skolelukninger i Kommunalreformens skygge? En analyse af Kommunalreformens policy-konsekvenser', Tidsskriftet Politik, vol. 13, no. 3, pp. 28-37.

Dahl, R A og E R Tufte 1973, Size and Democracy, Stanford University Press, Stanford. 
Dahlgaard, J O og L H Pedersen 2010, 'Kommunesammenlægningernes betydning for kommunalpolitikernes motivation', Tidsskriftet Politik, vol. 13, no. 3, pp. 17-27.

Denters, B, M Goldsmith, A Ladner, P E Mouritzen og L E Rose 2014, Size and Local Democracy, Edward Elgar, Cheltenham.

Elklit, J og M N Pedersen 2006, Kampen om den nye kommune. Syv fortællinger fra den kommunale valgkamp 2005, Syddansk Universitetsforlag, Odense.

Eklit, J og U Kjær (red.) 2013, KV09. Analyser af kommunalvalget 2009, Syddansk Universitetsforlag, Odense.

Hansen, K M 2012, 'Kvantitative datakilder', side 287-301 i L B Andersen, K M Hansen og R Klemmensen (red.), Metoder i Statskundskab, 2. udgave, Hans Reitzels Forlag, København.

Hansen, K, B Bjørnholt, P K Jespersen, J A Nielsen og H Salomonsen 2008, Nye kommuner i støbeskeen - om organisering og styring $i$ de nye kommuner, Handelshøjskolens Forlag, København.

Hansen, S W \& U Hjelmar 2015, 'Når kommuner bliver større: de korte og mere langsigtede konsekvenser for lokaldemokratiet', Politica, vol. 47, no. 3, pp. 464-484.

Hansen, S W 2015, 'The Democratic Costs of Size: How Increasing Size Affects Citizen Satisfaction with Local Government', Political Studies, vol. 63, no. 2, pp. 373-389.

Hansen, S W 2013, "Polity Size and Local Political Trust: A Quasi-experiment Using Municipal Mergers in Denmark', Scandinavian Political Studies, vol. 36, no. 1, pp. 43-66.

Houlberg, K og H Larsen 2000, ‘Er kommunerne bæredygtige ind i det næste årtusind?', side 29-49 i P Dahler-Larsen og K K Klausen (red.), Festfyrvarkeri eller gravøl? En debatbog om den danske kommune ved årtusindskiftet, Odense Universitetsforlag, Odense.

Houlberg, K og L H Pedersen 2014, 'Political Consensus and Fiscal Outcomes', Local Government Studies, vol. 41, no. 1, pp. 78-99.

Jakobsen, M 2009, “Når administrativ inddeling påvirker politisk adfærd: Strukturreformen og lokal stemmeadfærd ved kommunalvalget i 2005', Politica, vol. 41, no. 3, pp. 349-372.

Jakobsen, M og U Kjær 2015, "Political Representation and Geographical Bias in Amalgamated Local Governments", Local Government Studies, vol. 42, no. 2, pp. 208-227, DOI: 10.1080/03003930.2015.1127225.

Kjær, U og R Klemmensen 2014, 'What are the Local Political Costs of Centrally Determined Reforms of Local Government?', Local Government Studies, vol. 41, no. 1, pp. 100-118. 
Kjær, U, U Hjelmar og A L Olsen 2010, 'Democratic Functioning of Local Councils: The Case of The Danish 2007 Structural Reform', Local Government Studies, vol. 36, no. 4, pp. 569-585.

Kjær, U og J Elklit 2010, 'Party politicisation of local councils: Cultural or institutional explanations for trends in Denmark, 1966-2005', European Journal of Political Research, vol., 49, no. 3, pp. 337-358.

Kjær, U og P E Mouritzen (red.) 2003, Kommunestørrelse og lokal demokrati, Syddansk Universitetsforlag, Odense.

KREVI 2009, Strukturreformen udfordrer nærdemokratiet. Aarhus: KREVI.

Lassen, D D og S Serritzlew 2010, 'Kommunalreformen og lokalpolitisk effektivitetsfølelse', Politica, vol. 42, no. 2, pp. 145-162.

Lassen, D D \& S Serritzlew 2011, 'Jurisdiction Size and Local Democracy: Evidence on Internal Political Efficacy from Large-scale Municipal Reform', American Political Science Review, vol. 105 , no. 2 , pp. $238-258$.

Meyer, B D 1995, 'Natural and Quasi-Experiments in Economics', Journal of Business \& Economic Statistics, vol. 13, no. 2, pp. 151-161.

Mouritzen, P E (red.) 2006, Stort er godt. Otte fortællinger om tilblivelsen af de nye kommuner, Syddansk Universitetsforlag, Odense.

Nielsen, T S og C Vestergaard 2014, 'Kommunestørrelse og demokrati - effekten af kommunestørrelse på borgernes eksterne politiske effektivitetsfølelse', Politica, vol. 46, no. 2, pp. 219-236.

Olsen, A L 2010, 'Kommunalreformens konsekvenser: Kommunalpolitikernes rolle, borgernes lokaldemokratiske opfattelse og den administrative organisering', Tidsskriftet Politik, vol. 13, no. 3, pp. 38-47.

Verba, S og N H Nie 1972. Participation in America: Political Democracy and Social Equality, Harper \& Row, New York.

Wooldridge, J M 2009. Introductory Econometrics: A Modern Approach, 4. udgave, Cengage, Independence. 